\title{
Evaluating the Relationship between National Park Management and Local Communities' Perceptions Based on Survey, a Case of Nyungwe National Park, Rwanda
}

\author{
Anathalie Nyirarwasa1,2,3, Fang Han 1,2*, Xumei Pan',2, Richard Mind'je ${ }^{1,2,3}$, \\ Albert Poponi Maniraho1,2,3, Aboubakar Gasirabo1,2,3, Madeleine Udahogora ${ }^{1,2}$, \\ Zacharia Florence Mtewele ${ }^{2}$, Edovia Dufatanye Umwali1,2,3
}

\author{
${ }^{1}$ State Key Laboratory of Desert and Oasis Ecology, Xinjiang Institute of Ecology and Geography, Chinese Academy of Sciences, \\ Urumqi, China \\ ${ }^{2}$ University of Chinese Academy of Sciences, Beijing, China \\ ${ }^{3}$ University of Lay Adventists of Kigali (UNILAK), Kigali, Rwanda \\ Email: rwasan123@hotmail.com, *hanfang@ms.xjb.ac.cn, panxumei15@mails.ucas.ac.cn, \\ mindjerich@gmail.com, arbertpoponi@gmail.com, gasirabo1@gmail.com, \\ zachafrom100@gmail.com,udahogoram@gmail.com,umwariedovia@outlook.com
}

How to cite this paper: Nyirarwasa, A., Han, F., Pan, X. M., Mind'je, R., Maniraho, A. P., Gasirabo, A., Udahogora, M., Mtewele, Z. F., \& Umwali, E. D. (2020). Evaluating the Relationship between National Park Management and Local Communities' Perceptions Based on Survey, a Case of Nyungwe National Park, Rwanda. Journal of Geoscience and Environment Protection, $8,108-126$.

https://doi.org/10.4236/gep.2020.812007

Received: November 1, 2020

Accepted: December 13, 2020

Published: December 16, 2020

Copyright ( 2020 by author(s) and Scientific Research Publishing Inc. This work is licensed under the Creative Commons Attribution International License (CC BY 4.0).

http://creativecommons.org/licenses/by/4.0/ (c) (i) Open Access

\begin{abstract}
A sustainable management of national park requires collaboration between park staff, NGOs, local organizations and stakeholders, and government intervention. This collaboration promotes community-based welfare and inspires a sense of responsibility, thus promoting more benefits than conflicts. A survey administered to residents surrounding Nyungwe National Park was used to evaluate the relationship between Nyungwe National Park management and local communities. The residents acknowledged a positive attitude towards participating in conservation organizations where there was involvement, while a negative response revealed weak community mobilization. The community's opinions about protection and tourism progression noted weak conflict resolution, but a positive attitude towards tourism activities in the area since they believed employment was likely as a result. In addition, the residents asked for support from government investments and stakeholders to develop the local private sector, and asked to be involved during the planning process. Approaches including the design of coordination mechanisms and integrated conservation and developments projects are suggested to promote a management structure leading to community involvement in conservation and tourism activities. This will increase visitor numbers and contribute to economic development not only in the region but also in the whole
\end{abstract}


country. Empirical studies along with the factors shaping tourism and conservation activities should be considered as the basis for sustainable decision and policy making for sustainable management, and will contribute to government, stakeholders and park manager collaborations at Nyungwe national park.

\section{Keywords}

National Park Management, Local Communities, Implementation, Residents' Attitudes Coordination Mechanism

\section{Introduction}

A well-managed national park has a competent and appropriate strategy to preventing biodiversity loss and climate change, and improving local society while maintaining essential ecosystem functioning, on which humanity worldwide depends (He \& Cliquet, 2020; Lopoukhine et al., 2012). The aims of the protection policies should be decentralized to central institutions authority including conservation and tourism organizations. The WPC (World Park Congress) is the institution that has established plans, with goals including compensating local communities who lack access to protected areas. It provides benefits that would allow communities to profit economically, while avoiding environmental degradation. These must be functioned in four procedures: planning, controlling, organizing, and implementing at central and local levels (Worboys, Lockwood, Kothari, Feary, \& Pulsford, 2015). The achievement of the purposes might intervene participatory approaches (Pimbert \& Pretty, 1997), stakeholder approaches (Donaldson \& Preston, 1995), community-based management (Jamal \& Getz, 1995), and Integrated Conservation and Development Projects (ICDP) (Barrett \& Arcese, 1995). These, will transform residents' attitudes from nonparticipation to responsibility and shape an attitude of decision and ownership in tourism destinations (Dinham, 2005; Park, Zielinski, \& Jeong, 2020).

The success of conservation and tourism management rules should be characterized by a good interaction between protected area and people, when more independent and dependent participants are being evaluated (Allendorf, Hohenlohe, \& Luikart, 2010). These relationships have previously failed to reflect a natural balance between humans and the environment, clarifying the effect of rapid population growth on natural resources exploitation (Hancock, 1985). Rapid growth of population and its outcomes, involving land scarcity, lack of education, poverty and the genocide against Tutsi, were mentioned as the prior challenges of Rwanda management policies. The environmental restoration associated with government institutions is supported by the Rwanda Development Board formal (RDB), formerly the ORTPN (Office Rwanda du Tourism Parc Nationaux) in collaboration with Wildlife Conservation Society (WSC). Through education, local NGOs known as ANICOs (Animator de conservation) have tried to strengthen the protection of regions such as Nyungwe National Park, 
Mukura, and Gishwati since 1923, followed by VNP (Virunga National Park) in 1925, ANP (Akagera National Park) in 1934. Moreover, the Gishwati-mukura forest was assigned as Biosphere Reserve by the United Nations Education, Scientific and Culture Organization on $28^{\text {th }}$ October, 2020. The target was to extend protection of the country's land to about $10 \%$ of the total area; however the return of refugees from Uganda, Kenya and Tanzania has been noted as the primary challenge to management because of the reduction in park area to accommodate them (Nibeza, 2015).

Local communities in collaboration with government institutions along with knowledge about the sites can promote internal and external tourism activities (Zamil, 2011). Those activities may bring more benefits than inconveniences, such as socio-economic development, knowledge, local business such as handcrafts, and friendship (Armstrong, 2012). However, people in remote rural areas are vulnerable to unemployment, poverty, poor health and lack of education. Tourism activities can not only influence residents' attitudes, but also improve knowledge about environmental conservation (Arjunan, Holmes, Puyravaud, \& Davidar, 2006; Rastegar, 2017). The factors including, people age, family size, gender and household income characterize the development of attitudes about the protection of biodiversity should promote achievement (Anthony \& Govindarajan, 2007).

A survey administered by (Struhsaker \& Siex, 2005) covering 16 protected forest areas in Africa was established that a positive attitude towards National Parks in the surrounding communities was importantly related with the success of the Parks, though there were weak mobilizations and outreach programs. Using the same methodology to investigate 93 large strictly $\mathrm{p}$ areas, argued that residents' participation was only correlated with protection success owing to the existence of compensation schemes in tropical regions, by Bruner, Gullison, Rice, \& Da Fonseca (2001). Holmes (2003) argued that, residents experiencing interaction with PA staff had a more positive attitude towards PAs than those who did not experience collaboration. Allendorf (2010) proved that, people's perceptions of other entities, such as NGOs working in the destination area, may also influence their attitudes. Davis \& Morais (2004) noted that, community adaptation theory suggests by adjusting to tourism, residents' attitudes may become more positive, but can become negative if they cannot adapt to the project, as explained in a case in Arizona.

In developing countries, the execution of conservation approaches has often not been achieved due to inadequate governance, weak management plans and ineffective legal systems (Salafsky \& Wollenberg, 2000). Ormsby \& Kaplin (2005) revealed that, positive perceptions of the benefits of parks can predict people's attitudes towards conservation, combined with attractions, both natural and man-made, by making destination more competitive in Madagascar. It was discovered that the poorest residents are dependent on forest exploitation, in East Africa, that increase threats to wildlife are increased by Malhi et al. (2010). In Rwanda, Moore et al. (2018) revealed that the success or failure of conserva- 
tion-oriented parks can be weakened by poor management, limited entrepreneurial skills, lack of involvement in the project, unsuccessful implementation and inadequate funding in Rwanda. Furthermore, transparency and fairness were associated with authorities overemphasizing strict restrictions rather than motivation by Sharpley \& Pearce (2007), as results of ignorance and breaking imposed rules. Hence, resource access, institutional, people-park, benefits sharing, transboundary, buffer zone, and wildlife-human (to address crop raiding by animals) were triggered the conflicts which have affected the management strategies of the Park by Crawford (2012). These mentioned past issues have resulted in the loss of some species from the park, in 1974, when buffaloes were killed by hunters; 1997, when $5 \%$ to $8 \%$ of the park was consumed by fires; and 1999 when elephants were killed by poachers. This was launched in 2012 by the CSC (Conflicts sensitive Conservation), and the responsible institutions have failed to make an appropriate collaboration concerning the agreement of eliminating the mining productions in Nyungwe Forest national park.

However, the previous study highlighted the effect of unfair management and involvement as the difficulties of conservation and tourism achievement, lack of understanding, the contribution of residents' perception towards participating in local conservation organization will help to understand the appropriate way of planning. This can be input for evaluating the proposed statements to empower a sustainable collaborating with stakeholders and governments institutions concerning tourism promotion in destination. Nonetheless, this study will serve as a baseline of applying different theories and approaches that should assist during the park management plans and decision-making towards expanding tourism development and livelihood status in the region. Therefore, this study surveyed the objectives of: 1) Analyzing the factors that influence communities interacting with park' conservation policies; 2) Evaluating residents' attitudes by defining the factors that shape positive or negative impacts with regard to conservation and tourism expansion 3) Defines some suggestion provided by residents concerning stakeholders and local government collaboration on improving them during decision-making and projects implementation.

\subsection{Tourism Development and Management Process in Nyungwe National Park}

Tourism is a global business, which has expanded over the previous three decades into a complex system, with progress in economic, social and educational environments (Holden, 2016). Protected areas enhance the sustainability of tourism activities through conservation. National Parks have the ability to develop the economy, which in return can offer enough benefits to offset the costs of conservation and support local people's livelihoods (Eagles, 2014). A major strategy has been designing revenue-generating opportunities by providing sustainable occupations for youths, both educated and unskilled (Saner, Yiu, \& Filadoro, 2019). Furthermore, tourism is dependent on the environment at the broad- 
est level, and ecosystems require people management worldwide (FARAJIRAD \& AGHAJANI, 2010). The National park of Nyungwe management policies have characterized by the following events: In 1933 the Nyungwe forest was declared as Nyungwe forest reserve, in 1983 and 1990 the forest noted buffer zone creation; 1987 and 1990 introducing the program concerning tourism development; in 1991; developing tourism center in Nyungwe forest reserve; 2001, the government of Rwanda proposed to name the forest reserve as Nyungwe forest National park, and 2005 the forest reserve was finally announced as Nyungwe national park; in 2008, the national park of Kibira in Burundi Instutut National pour l'Environment Conservation de la Nature (INECN) corroborated with ORTPN in Rwanda under wild Society Conservation (WSC) for solving the issues of transboundary, and 2010, the park established the canopy walking. For the purpose of improving ecosystem development, reforestation, along with ecological corridor connecting Nyungwe-Gishwati and Mukura forests, has considered the free movement of chimpanzees between habitats (Koellner et al., 2013). Moreover, the development of buffer zone corridors, ecologically sensitive zones, wilderness zones, and Tourism Development Zones (TDZs), has empowered tourism development in NNP (Chew, 1990).

Rwanda economic development has identified tourism as a priority sector for funding, as declared in the Vision 2020 strategy. While the revenues generated from Rwandan national parks counted as the major sources of income. The additional related tourism profits were estimated to be 5\% of total GDP in 2005 (Gatsinzi \& Donaldson, 2009), and continued to increase by $18.8 \%$ in 2011/2012. NNP is receiving insufficient proportions of visitors compared with Akagera and Virunga National Parks (14\%, 45\%, and 41\% respectively) in 2014. The factors impeding participation may include poverty, lack of interest among residents and long journeys form other attractive settings and cities. The NNP attractions were destroyed during the Tutsi genocide in 1994, especially at Uwinka station, and renewal involved a large budget and a long period of time. Figure 1 illustrates the visitors to NNP from 2005 to 2017.

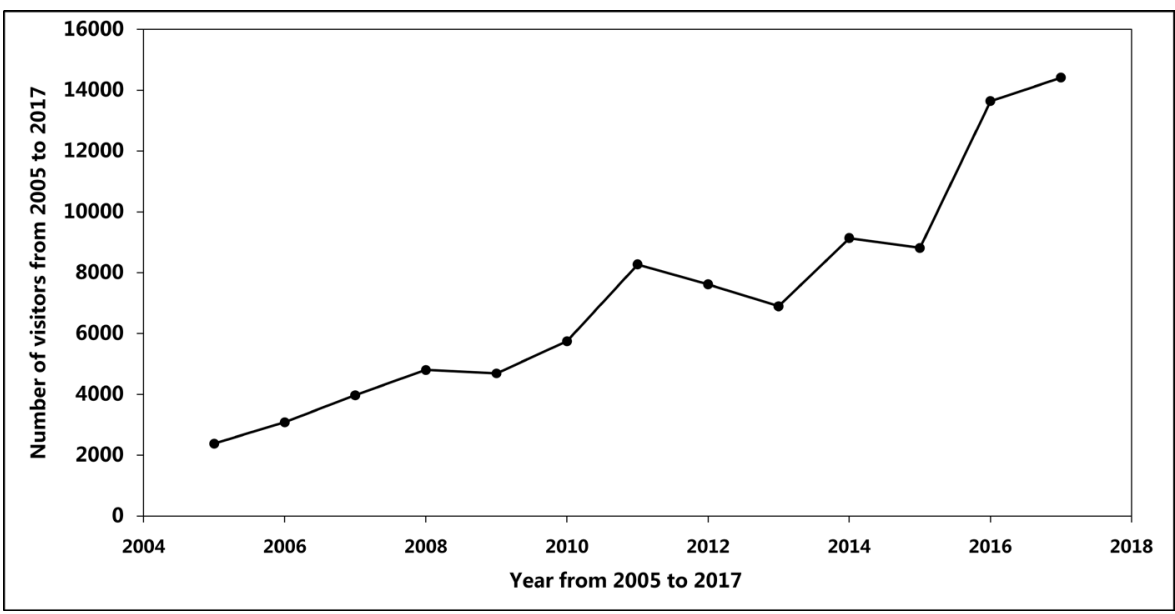

Figure 1. Source RDB, statistical yearbook 2019 with number of visitors from 2005 to 2017. 


\subsection{Study Area Description}

Nyungwe National Park (NNP) is the largest tropical mountain forest park in Africa. It is recognized as a site of important biodiversity and endemic species in the Albertine Rift eco-region. It lies at latitude $02^{\circ} 15^{\prime} \mathrm{S}-02^{\circ} 55^{\prime} \mathrm{S}$ and longitude $29^{\circ} 00^{\prime} \mathrm{E}-29^{\circ} 30^{\prime} \mathrm{E}$ with elevations ranging from 1600 to $2950 \mathrm{~m}$ above sea level. It is estimated to cover an area of $1032 \mathrm{~km}$. The temperature is generally cool, with an average minimum of $10.9^{\circ} \mathrm{C}$ and a maximum of $19.6^{\circ} \mathrm{C}$, and $1744 \mathrm{~mm}$ annual mean rainfall (Kaplin \& Moermond, 1998). The park is classified as a category IV area by IUCN (International Union for Conservation of Nature) owing to its purposes of restoring species and habitats, while protecting vegetation through traditional approach that provides a means by which urban residents may obtain regular contact with nature. It hosts abundance of plants and wildlife: including threes and shrub over 260 species, where some endemic of Albertine Rift notified 24 species. The forest hosts 13 varieties of primates including chimpanzees, colobus monkeys (both Angola black and Angola white), and owl-faced guenons (Plumptre et al., 2002). NNP has been connected with the Cyamudongo forest since 1960, in the north east. It is connected to Kibira National Park in Burundi, and the two National Parks share many species. Nyungwe-Kibira National Parks have unique groups of Angola colobus monkeys, which form a large groups of over 400 individuals (Fashing et al., 2007; Polisi et al., 2017) NNP contains the Nile Congo river basin.

The surrounding population density is approximately 160 to $880 / \mathrm{km}^{2}$. The forest's ecological tempering effects result in long periods of rain each year and only minor dry seasons occur, from July to August, and from December to January. NNP has tea plantations both on its buffer zone, and inside (Gross-Camp, Martin, McGuire, \& Kebede, 2015). NNP is located in five districts, of which three-Nyamagabe, Karongi and Nyamasheke were selected for the current study. The neighboring districts are Kibeho, Kirehe, Cyesha, Nyamagabe, and Cyangugu. In Nyamagabe district, the Nkomane sector, with two cells named Mutengeri and Nyarwungo, was selected. In the Karongi district, the selected sector was Twumba, with Gisovu and Gakuta cells, while in the Nyamasheke district, Gasovu and Rushyarara were selected. Generally, the main income in these areas is from maize and tea production), forestry (timber exploitation, traditional medicine), livestock, and small businesses.

\section{Materials and Methods}

\section{Data Collection and Analysis}

A survey of questionnaire was used to collection occurred from 22 August to 25 August 2020, and a pre-survey using face-to-face interviews was conducted after investigation completion. This was occurred in the local community, including, the leaders of residents, handcraft manufacturers and conservation organizations situated near NNP to verify whether the questionnaire was reasonable and goal-oriented. To develop our measurement tools, we first created a list of con- 
servation and tourism facts based on the literature review declaration, which included over 20 indicators. A complete randomization (simple random sampling) method was performed (Wilcox, 2008), whereby participants were selected by giving them equal chance, treatments, interventions or opportunity to respond to the design questionnaire. Among the five districts neighboring the study area, only three were chosen to take part selection of participants. In each selected district, three sectors were randomly selected in which 2 cells were also selected making a total number of 6 cells. Finally, 25 households per each cell were randomly sampled to respond to the designed questionnaire, making a total of 150 households. The questionnaire requires to achieve the objectives with three categories including, closed ended and multiple-choice questions which were distributed in each cell in a total of 25 checkups. Firstly, background information on the socio-demographic and socio-economic characteristics of households. Secondary, the skills of local communities were relating to NNP and their interaction with the park's management towards conservation. In this category, the statements concerning the growth of population on the natural resources of NNP were involved, and 5-point Likert scale approach was performed. Third, the negative and positive statements concerning the attitudes of local residents concerning tourism and conservation were evaluated. In this section, the combination of socio-demographic variables and people-park interactions such as, study site (existence of protected area named Nyungwe national Park), number of households $(\mathrm{HH})$, occupation, Int PA Staff (Interaction with Protected area staff), aware of non-government organizations (Local NGOs), benefit, Grazing, and problems were independent variables. The proposed statements were examined attitudes in function of conservation and tourism contribution. Then, a binary combination analysis along with principal component analysis (PCA) were performed using the Statistical Package for Social Sciences (SPSS 1.7) to determine the factors that may be strongly escalating positive impacts regarding NNP's conservation. Finally, a list of six proposed statements was used to evaluate the perceptions of residents towards instructional government and stakeholders, on improving them in tourism development and conservation.

\section{Results Analysis}

\subsection{Description of Socio-Economic and Demographic Factors}

The results in Table 1 indicated that gender characteristics questions showed that $57.3 \%$ of respondents were male and $42.7 \%$ were female. The high number of males represents the family leader. The highly respondents (40\%) were aged between 31 and 45 years. In this age group the respondents were mature and active, and the information they provided was credible. The smallest percentage was recorded for household leaders aged 61 years and above. The analysis of education status showed that $44.7 \%$ of respondents had attended primary school, $18.7 \%$ of respondents were illiterate, $32.7 \%$ skilled from high school, and only $4 \%$ had attended university. The unskilled population was dominated by 
Table 1. Socio-economic and demographic characteristics of respondents.

\begin{tabular}{|c|c|c|c|}
\hline Variables & Category & Frequency & Percentage (\%) \\
\hline \multirow{2}{*}{ gender } & Female & 64 & 42.7 \\
\hline & Male & 86 & 57.3 \\
\hline \multirow{4}{*}{ Age } & $18-30$ & 49 & 32.7 \\
\hline & $31-45$ & 60 & 40 \\
\hline & $46-60$ & 26 & 17.37 \\
\hline & Above 60 & 15 & 10 \\
\hline \multirow{4}{*}{ Education } & Illiterate & 28 & 18.7 \\
\hline & Primary & 67 & 44.7 \\
\hline & High school & 49 & 32.7 \\
\hline & University & 6 & 4 \\
\hline \multirow{4}{*}{ Living years } & Less than 1 year & 0 & 0 \\
\hline & $1-4$ & 9 & 6 \\
\hline & $5-10$ & 21 & 14 \\
\hline & Above 10 & 120 & 80 \\
\hline \multirow{3}{*}{ Family size } & $1-3$ & 49 & 32.5 \\
\hline & $4-8$ & 97 & 65 \\
\hline & 8 above & 4 & 2.5 \\
\hline \multirow{4}{*}{ Occupation } & Farming (cropping and animal rearing) & 89 & 59.2 \\
\hline & Own business & 21 & 14.2 \\
\hline & Wage labor & 29 & 19.2 \\
\hline & Other & 11 & 7.5 \\
\hline
\end{tabular}

residents earning a living from traditional activities such as farming and animal grazing. The majority (80\%) of informants had lived in their area over 10 years. This indicated that information provided was reliable and useful since these individuals had resided in the area for a long time and the information, they provided was likely to be based on local knowledge. Household data showed that $65 \%$ of households had 4 to 8 members. (Large increases in human population have a major impact on resource depletion). The Occupation status data showed that $59.2 \%$ percent of the consulted households lived by farming (rearing animals and horticulture). High levels of occupancy in farming sectors require large areas of land, which may create conflicts with National Parks, leading to negative views on interacting with parks. The occupation data also showed that $19.2 \%$ of those surveyed were wage laborers. Other activities and business ownership accounted for $7.5 \%$ and $14.2 \%$ respectively.

\subsection{Factors Influencing People-Park Interaction}

\subsubsection{People-Park and Grazing}

All 150 respondents confirmed that there was a protected area near their neighborhood and highlighted the NNP (Nyungwe National Park). All respondents 
also indicated that they didn't graze animals in the park, mainly because the boundaries of the park are clear and their fines to be paid for grazing within the boundaries.

\subsubsection{Existence of Park Management Community-Based Organization}

It was noticed that among the communities surrounding the NNP, there are somecommunity-led organizations in charge of ensuring that wild animals and forest biodiversity are conserved properly without harm. These associations were found mainly in the Karongi and Nyamagabe districts and they were ranked at $52.7 \%$ (Table 2). In addition, Table 2 shows that $42.7 \%$ of respondents participated in the management of the park. However, there is still a knowledge to encourage/motivate local communities to participate in park conservation initiatives, especially in Nyamasheke district. The benefits of being located near the park were highlighted by all respondents, including those from Nyamasheke district. The following section presents the benefits and problems associated with being located close to the park.

\subsubsection{Community Interaction with Park Management and Responsible Entities}

The results in Table 3 showed that $65.3 \%$ of respondents confirmed that park management interactions took place in their living areas during local meetings, with 34.7\% highlighting that such interactions happened during training on park management. With regard to interaction with hosting entities, it was found that the local leaders had a high percentage (50\%) of interaction with local communities in motivating them to join the park management, while the staff of the park (those in charge of park management) were at $27.3 \%$, and NGOs at $22.7 \%$.

\subsubsection{Benefits and Problems Associated with Living near the NNP Park}

The respondents, as indicated in Table 4, mentioned many benefits resulting from being located near the park. It was noted that $32 \%$ of informants benefited from health centers and schools near the park while electricity and the roads that link the park and surrounding areas were highlighted by 26 and $24.7 \%$, respectively. The results in Table 4 indicate that people located close to NNP also benefit from frequent rainfall, which enables them to grow crops even during dryer periods. Table 4 also shows that with regard to problems associated with being near the park, $46.7 \%$ of respondents mentioned that wild animals from the park damage their crops, whereas $53.3 \%$ declared no problems.

Table 2. Locally-based park conservation and community participation.

\begin{tabular}{cccc}
\hline & & Frequency & Percentage (\%) \\
\hline \multirow{2}{*}{ Park conservation organizations } & Yes & 79 & 52.7 \\
& No & 71 & 47.3 \\
\hline \multirow{2}{*}{ Community involvement in park management } & Yes & 64 & 42.7 \\
& No & 86 & 57.3 \\
\hline
\end{tabular}




\subsubsection{Impact of Population Growth and Nyungwe Park Management}

While obtaining field data in this section, the researcher requested respondents to rank statements using the following scale: 1 = Strongly disagree (SD), 2 = Disagree (D), $3=$ Neutral (N), $4=$ Agree (A) and $5=$ Strongly agree (SA).

The results in Table 5 indicate that $68.3 \%$ of informants strongly agreed that population growth will occupy land belonging to the park. In addition, Table 5 shows that population growth is seen as likely to reduce NNP's wild animals and its biodiversity. Similarly, $80.8 \%$ strongly agreed that population growth and industrialization cause climate change, disasters and the park's resources depletion.

\subsection{Local Communities' Attitudes towards Conservation and Tourism Development}

As revealed in Table 6, among the consulted respondents, $76.7 \%$ of them strongly agreed that tourism increases infrastructure in tourism destinations. This agrees with the results in Table 4, in which more than $80 \%$ of residents

Table 3. Types of interaction between communities and their hosts.

\begin{tabular}{cccc}
\hline & & Frequency & Percentage (\%) \\
\hline \multirow{2}{*}{ Interacting with park management } & Park mgt training & 52 & 34.7 \\
& Local meetings & 98 & 65.3 \\
\hline \multirow{2}{*}{ Interaction with entities } & Park staff & 41 & 27.3 \\
& Local leaders & 75 & 50 \\
& NGOs & 34 & 22.7 \\
\hline
\end{tabular}

Table 4. Benefits and problems associated with living near the NNP.

\begin{tabular}{|c|c|c|c|}
\hline & & Frequency & Percentage (\%) \\
\hline \multirow{4}{*}{ Benefits from park } & Health centers and schools & 48 & 32 \\
\hline & Frequent rainfall & 26 & 17.3 \\
\hline & $\begin{array}{c}\text { Constructed roads linking park } \\
\text { and surrounding areas }\end{array}$ & 37 & 24.7 \\
\hline & Electricity & 39 & 26 \\
\hline \multirow{2}{*}{ Problems from park } & Wild animals damage crops & 70 & 46.7 \\
\hline & None & 80 & 53.3 \\
\hline
\end{tabular}

Table 5. Population growth impact and its development activities on the park.

\begin{tabular}{|c|c|c|c|c|c|c|}
\hline \multirow{2}{*}{ Facts } & \multicolumn{5}{|c|}{ Rank } & \multirow{2}{*}{ Total } \\
\hline & 5 & 4 & 3 & 2 & 1 & \\
\hline Population growth leads to park land occupation & 68.33 & 19.17 & 0 & 5 & 7.5 & 100 \\
\hline $\begin{array}{l}\text { Population growth reduces wild animal } \\
\text { populations and threatens biodiversity }\end{array}$ & 59.17 & 25.83 & 0 & 9.17 & 5.83 & 100 \\
\hline $\begin{array}{l}\text { Population growth and industrialization cause climate } \\
\text { change, disasters and resource depletion in the park }\end{array}$ & 80.83 & 19.17 & 0 & 0 & 0 & 100 \\
\hline
\end{tabular}


Table 6. Community attitudes towards conservation and tourism development.

\begin{tabular}{|c|c|c|c|c|c|c|}
\hline \multirow{2}{*}{ Perceptions } & \multicolumn{5}{|c|}{ Rank } & \multirow{2}{*}{ Total } \\
\hline & 5 & 4 & 3 & 2 & 1 & \\
\hline $\begin{array}{l}\text { Tourism reduces conflicts between people and park (that is why they apply for encouragement } \\
\text { to improve the park as a destination) }\end{array}$ & 0 & 0 & 0 & 40.8 & 59.2 & 100 \\
\hline Tourism can create employment and income for neighboring residents & 67.5 & 32.5 & 0 & 0 & 0 & 100 \\
\hline Tourism increases infrastructures in tourism destinations & 76.7 & 23.3 & 0 & 0 & 0 & 100 \\
\hline Tourists purchases local produce, supporting other sectors of the local wider economy & 38.2 & 8.3 & 9.9 & 20.9 & 22.7 & 100 \\
\hline Tourism enhances conservation of the park's natural resources & 70 & 22.5 & 0 & 7.5 & 0 & 100 \\
\hline Tourism benefits motivate local people to conserve the Nyungwe forest park & 69.2 & 19.2 & 0 & 8.3 & 3.3 & 100 \\
\hline Tourism causes illegal displacement of people away from their natural resource heritage & 10.7 & 20.3 & 1.7 & 28.3 & 39 & 100 \\
\hline $\begin{array}{l}\text { Tourism enhances over-exploitation of resources through pressure and law on local people } \\
\text { to conserve habitats and wildlife }\end{array}$ & 10 & 26 & 3.3 & 15 & 40.7 & 95 \\
\hline Unequal sharing of tourism revenues delays conservation activities & 48 & 20 & 5.7 & 14 & 10.3 & 98 \\
\hline Tourism poses a threat to natural resources and preservation of the national park & 40.8 & 10.3 & 20.7 & 10 & 18.2 & 100 \\
\hline Tourism development should be actively encouraged in my community & 57.5 & 31.7 & 0 & 7.5 & 0 & 96.7 \\
\hline
\end{tabular}

Note that the incomplete totals were obtained as the level agreement and disagreement resulted from the incomplete filling of the questionnaire due to lack of logic' skills and of respondents and fear of the survey purpose.

stated that they benefited from health centers, schools, electricity and roads that had been constructed linking the park and its surrounding areas. However, respondents strongly disagreed that tourism reduces conflicts between people and the park. This was mentioned by $59.2 \%$ of respondents. In addition, as exposed in Table 6, only 38.2 percent of informants strongly agreed that tourists purchase local produce, supporting other sectors of the local wider economy. However, $57.5 \%$ strongly agreed that tourism development should be actively encouraged in their communities. Residents mentioned illegal displacement with only weak agreement since most of them had lived there exceeded 10 years; however, $10.7 \%$ noted issues related to functions of their land, such as conversion into tea plantations.

\subsection{Factors Influencing the Participation in Conservation and Tourism Development in NNP}

For this section, the researcher analyzed the people-park interaction and then predicted the success of conservation rules, and expansion of tourism activities. The results in Figure 2 indicate that community members' occupations (farming, wage labor, own business and other types) along with the number of household members, which is an indication of population growth, are likely associated with poor park tourism and conservation activities. However, regardless of the above, local organizations operating close to the community will enhance their understanding of and participation in the conservation of the park. Gender had no contribution impact on the park, while the benefits are contested, with moderate positive impact on conservation and tourism development. Furthermore, grazing, park staff and study site were correlated in the center 0 axis, 
which signifies that those variables should have a strong impact on park management or degradation. However, the park staff can create local organizations, which can support the park's conservation.

Based on the results in Table 7, of the respondents consulted, $83.3 \%$ strongly

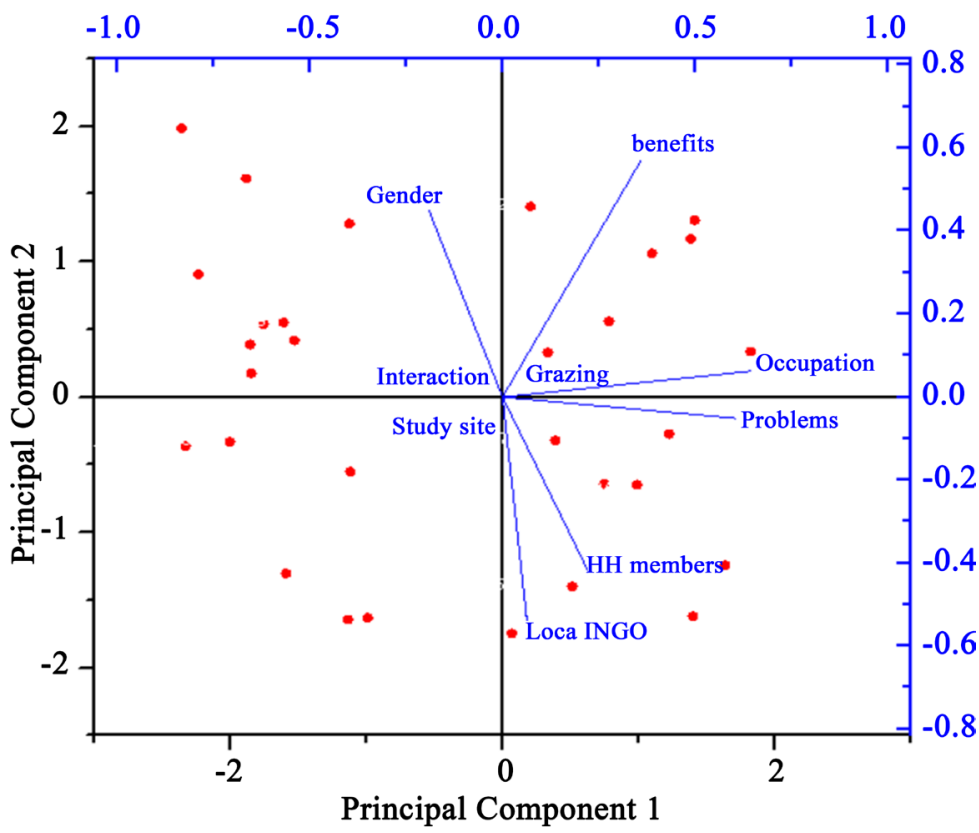

Figure 2. Principal Component Analysis (PCA) describing the consequences influences of socio-demographic factors (gender, occupation, study site, park staff, grazing, problems, benefits, $\mathrm{HH}$ (households) members, and Non-government organizations, on strengthening positive impacts regarding conservation and tourism participation (Tour \& consv) for Nyungwe Park tourism and conservation.

Table 7. Park conservation involvement and tourism improvement.

\begin{tabular}{|c|c|c|c|c|c|c|}
\hline \multirow{2}{*}{ Proposed statements } & \multicolumn{5}{|c|}{ Rank } & \multirow{2}{*}{ Total } \\
\hline & 5 & 4 & 3 & 2 & 1 & \\
\hline $\begin{array}{l}\text { Government should allocate part of the tourism revenue } \\
\text { to local community livelihoods to motivate local residents }\end{array}$ & 65.8 & 34.2 & 0 & 0 & 0 & 100 \\
\hline $\begin{array}{l}\text { The government of Rwanda should involve communities } \\
\text { in decision-making regarding conservation and tourism } \\
\text { development in Nyungwe National Park }\end{array}$ & 76.7 & 23.3 & 0 & 0 & 0 & 100 \\
\hline $\begin{array}{l}\text { Government should provide investment opportunities in } \\
\text { tourism to the private sector and local residents }\end{array}$ & 81.7 & 10 & 5 & 0 & 0 & 96.7 \\
\hline $\begin{array}{l}\text { More and regular interactions between Nyungwe } \\
\text { management and the surrounding communities would } \\
\text { help to ensure sustainable tourism and park management }\end{array}$ & 83.3 & 16.7 & 0 & 0 & 0 & 100 \\
\hline $\begin{array}{l}\text { Tourism institutions involve local communities during, } \\
\text { tourism plan and projects }\end{array}$ & 84.2 & 14.1 & 1.7 & 0 & 0 & 100 \\
\hline $\begin{array}{l}\text { National Park regulations should be relaxed to facilitate } \\
\text { tourism activities }\end{array}$ & 28.3 & 56.7 & 10 & 5 & 0 & 100 \\
\hline
\end{tabular}

Note that the incomplete total was obtained as the level agreement and disagreement resulted from the incomplete filling of the questionnaire due to lack of logic' skills and of respondents and fear of the survey purpose. 
agreed that more and regular interactions between NNP management and the surrounding communities would help to ensure sustainable tourism and park management. However, $84.2 \%$ indicated that the institutions in charge of tourism should involve local communities in tourism plans and projects. In addition, respondents suggested that to ensure tourism development and park management, there should be a relaxation of regulations in order to facilitate tourism activities in the NNP (Table 7).

\section{Discussion}

\subsection{Factors Influencing People-Park Interactions in Management Strategies}

This study investigated management of Nyungwe National Park in relation to surrounding local communities in Figure 1. The residents noticed more information from local meetings by $65.3 \%$ and a few collaborations during park management training in Table 3. Then, entities such as park staff and NGOs showed weak communication with local communities; however, high interaction was noted with local leaders, which recommends improvement to allow local projects to succeed and contribute to poverty eradication. Community-based conservation organizations were highly regarded as a priority in influencing sustainable conservation in the Karongi and Nyamagabe districts. The lack of conservation institutions in Nyamasheke was seen as a consequence of lack of institutional motivation poverty, lack of education and weak collaboration. It was argued that more participation should be sought if there is to be expansion of local business sectors alongside implementation by (Davis \& Morais, 2004). In Nyamasheke district, local communities believe in contributing to conservation projects, and here more involvement is required. Local communities in both districts highlighted benefits with regard to infrastructure development, which were insufficient for their livelihoods. However, the residents did not mention any issues related to natural resource exploitation and benefit sharing, the of rapid growth of the population, defined by high number of households by $65 \%$ increase high occupancy in agricultural by $59.2 \%$, thus will affect the national parks land as indicated (Table 1). Moreover, high number of unskilled people can also influence fear of participating in other business sectors of creativities, which required a strong support from institutions and education. This issue must be considered not only by Nyungwe National Park management, but also all institutional in charge of protected areas in under developing countries, where agriculture is the basis income for local people.

\subsection{Positive and Negative Factors Influencing Conservation and Tourism Development}

Participation in conservation and tourism development will be weak or strong, depending on the levels of interaction, Holmes (2003). In this study, residents' attitudes were strongly positive, due to resident's involvement in conservation 
organizations. Attitudes to the benefits of NNP showed a moderate positive impact on Nyungwe National Park conservation. There was also moderate agreement about infrastructure development as a benefit, local people benefiting from temporary jobs to support their families, and small businesses such as arts and hand crafts in and around the park gaining support. The correlation between occupation (primarily agriculture) and number of households is likely to strongly increase negative impacts on ecosystem conservation. The communities highlighted a high percentage of disagreement, of 59.2\%, about the reduction of conflict influencing tourism activities in the destination (Table 6). This was noticed in the theory of human-nature interaction, where the rapid increase of human population is seen as the cause of a shift in earth's resource equilibrium. The crop raiding by wild animals issues is the basis of negative perceptions about wildlife conservation, resulting in poaching, has been launched as a priority issue in conflict sensitive conservation (CSC) in NNP Crawford (2012). Grazing study sites and park staff will have a positive impact if the park staff create conservation institutions in all surrounding communities. It was pointed out that in destinations where conservation institutions are established, tourism expands conservation rules by $70 \%$ in Table 6 and local non-governmental organizations indicate that it will have a strong positive impact on tourism and conservation activities. At this point, it is significant that residents know the role of tourism in a sense of conservation, and it is a better to reasoned that, a durable education (training) and collaboration might also increase the number of tourists (Figure 3), as it is being annually improved. This was observed that, when applying the fixed rules of protecting the forest as the Nyungwe National Park is the same period where visitors have started traveling to the park.

\subsection{Stakeholders, Local Government and Community Mobilization in Management Rules}

Positive environmental conditions are more expected to develop management strategies if there is a constructive political environment (Becken, 2017). Residents indicated agreement with participation in conservation activities and tourism development. In total, $65.8 \%$ of respondents from local communities requested the government to allocate funds from tourism revenues to support poverty reduction (Table 7). Additionally, 76.7\% strongly believe to participate in decision-making, which need a deeply coordination. The need for support for the private business in their area was mentioned by $81.7 \%$ of residents, and they also stated that benefits should be expanded beyond infrastructure development Table 4) to include innovation for small businesses and the creation of better lives. This was proved that government power, leadership, and other strategies are thoughtful in achieving sustainable tourism development by Mihalic (2016). As mentioned in Table 4, community interaction with park staff and NGOs is weak; however, there is strong agreement in Table 7 , with $83.3 \%$ of residents arguing for progressing in management policies. 


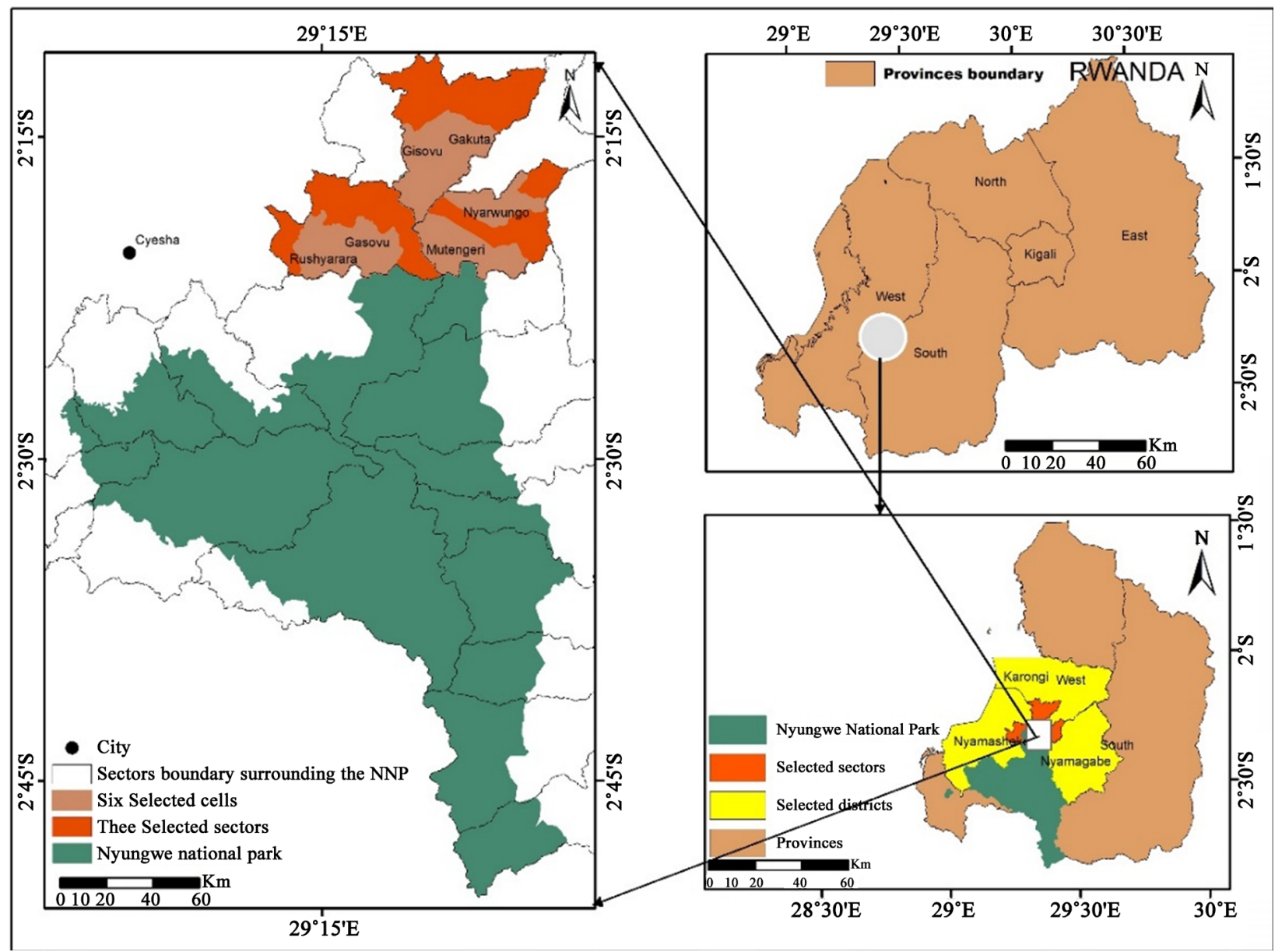

Figure 3. Study area description of the communities surrounding the NNP.

\section{Conclusion and Implication}

This paper examined the relationship between National Parks Management and local communities, and found a need for positive collaboration and more funding, as well as the implementation of local sectoral projects, which could help to motivate local communities to conserve and develop tourism in Nyungwe National Park. Currently many local residents are living in poverty, but with some benefits (infrastructure) received from tourism revenue. However, most local residents who have lived in the area for more than 10 years have been dependent on the exploitation of resources (for traditional medicine, food, often obtained by poaching, firewood, and building materials). The park management policies of Nyungwe National Park were started to shift residents from traditional mindsets to thoughts about tourism development. The perception in sense of tourism development beyond their traditional survives became difficulty, because the revenue from the tourism was insufficient to satisfy their need. Here, the government and park staff had to work closely with local residents, who were unsure about the new environment system and tourism situation, and faced many conflicts including land conversion and wildlife conflicts. Local leaders improved education in order to help residents feel they were members of the $\mathrm{Na}$ - 
tional Park; however, there was little funding and a lack of implementation of beneficial projects. In order to improve a sustainable park management, it is desirable to progress conservation and tourism development based on advancing the socio-economic development and livelihoods of local communities. Coordination (involving community participation and community franchise) and integrated projects development should propose and support the following:

- The coordination mechanism can be strengthened by the park managers and government authorities to allow flexibility that helps residents participate in internal and external plans. This will enable them to make decisions regarding protection and tourism progress. Management policies should collaborate with the government to resolve crop raiding conflicts, using local organizations since the residents are aware of the need for cooperation.

- Options proposed by communities with stakeholder and government involvement need to be considered (tourism revenue and investment opportunities). Residents believe in supporting tourism activities in their destination areas, and tourism activities should allocate institutions and community development projects that can provide job opportunities, training, education, and showcase innovative products throughout the region, which can support residents' incomes and create a spirit of participation.

- Local residents are aware of the need for conservation of the ecosystem; however, the benefits provided are inadequate to meet their desires. Residents need good interaction with park management policies via local organizations, which can be the basis of expanding conservation projects around the whole region.

- Additionally, the development of conservation projects should address the state of residents' development along with positive performance of ecological protection.

Although the present study has been successful to the knowledge relating managements policies and local communities in a sense of proposed statements regarding stakeholders and government support, the resident's perceptions towards conservation and tourism participation, along with conservation organization and management process, there was a limitation in the surveying process, since the authors were unable to investigate all districts surrounding the Nyungwe National Park due to travel restrictions in some districts including Rusizi and Nyaruguru as a consequence of the worldwide pandemic (novel corona Virus). Briefly, the study investigated the relationship between management policies of NNP and the perception of local communities, can influence achievement or failure according to extent of education, collaboration, and livelihoods improvement. The study achieved the important tips for improving management policies, in relation to projects based-implementation and community-based management. The variables such as benefits, conflicts and grazing resolutions need to be evaluated by future researchers, along with the impact of project developments in relation to participation and community livelihood development. 


\section{Acknowledgements}

The authors would like to acknowledge the Chinese Government, Xinjiang Institute of Ecology and Geography, and the projects of the National Natural Science Foundation of China (No. 41971192). Special thanks are owed to the editors and anonymous reviewers who gave constructive suggestions and comments for improving this article.

\section{Conflicts of Interest}

The authors declare no conflicts of interest regarding the publication of this paper.

\section{References}

Allendorf, F. W., Hohenlohe, P. A., \& Luikart, G. (2010). Genomics and the Future of Conservation Genetics. Nature Reviews Genetics, 11, 697-709. https://doi.org/10.1038/nrg2844

Allendorf, T. D. (2010). A Framework for the Park-People Relationship: Insights from Protected Areas in Nepal and Myanmar. International Journal of Sustainable Development \& World Ecology, 17, 417-422. https://doi.org/10.1080/13504501003788180

Anthony, R. N., \& Govindarajan, V. (2007). Management Control Systems.

Arjunan, M., Holmes, C., Puyravaud, J.-P., \& Davidar, P. (2006). Do Developmental Initiatives Influence Local Attitudes toward Conservation? A Case Study from the KalakadMundanthurai Tiger Reserve, India. Journal of Environmental Management, 79, 188-197. https://doi.org/10.1016/j.jenvman.2005.06.007

Armstrong, R. (2012). An Analysis of the Conditions for Success of Community-Based Tourism Enterprises (pp. 1-52). ICRT Occasional Paper (OP21).

Barrett, C. B., \& Arcese, P. (1995). Are Integrated Conservation-Development Projects (ICDPs) Sustainable? On the Conservation of Large Mammals in Sub-Saharan Africa. World Development, 23, 1073-1084. https://doi.org/10.1016/0305-750X(95)00031-7

Becken (2017). Tourism Planning in Natural World Heritage Sites: Griffith Institute for Tourism, Griffith University.

Bruner, A. G., Gullison, R. E., Rice, R. E., \& Da Fonseca, G. A. (2001). Effectiveness of Parks in Protecting Tropical Biodiversity. Science, 291, 125-128.

https://doi.org/10.1126/science.291.5501.125

Chew, S. T. (1990). Natural Resources Management: Issues and Lessons from Rwanda.

Crawford, A. (2012). Conflict-Sensitive Conservation in Nyungwe National Park: Conflict Analysis. Crawford: International Institute for Sustainable Development.

Davis, J. S., \& Morais, D. B. (2004). Factions and Enclaves: Small Towns and Socially Unsustainable Tourism Development. Journal of Travel Research, 43, 3-10. https://doi.org/10.1177/0047287504265501

Dinham, A. (2005). Empowered or Over-Powered? The Real Experiences of Local Participation in the UK's New Deal for Communities. Community Development Journal, 40, 301-312. https://doi.org/10.1093/cdj/bsi019

Donaldson, T., \& Preston, L. E. (1995). The Stakeholder Theory of the Corporation: Concepts, Evidence, and Implications. Academy of Management Review, 20, 65-91. https://doi.org/10.5465/amr.1995.9503271992

Eagles, P. F. (2014). Research Priorities in Park Tourism. Journal of Sustainable Tourism, 


\section{2, 528-549. https://doi.org/10.1080/09669582.2013.785554}

Farajirad, A., \& Aghajani, S. (2010). The Relationship between Tourism and Environment.

Fashing, P. J., Mulindahabi, F., Gakima, J.-B., Masozera, M., Mununura, I., Plumptre, A. J., \& Nguyen, N. (2007). Activity and Ranging Patterns of Colobus angolensis Ruwenzorii in Nyungwe Forest, Rwanda: Possible Costs of Large Group Size. International Journal of Primatology, 28, 529-550. https://doi.org/10.1007/s10764-006-9095-3

Gatsinzi, J., \& Donaldson, R. (2009). Investment in the Tourism Industry: The Experience of Rwanda. Journal for Development Support, 1, 33-49.

Gross-Camp, N. D., Martin, A., McGuire, S., \& Kebede, B. (2015). The Privatization of the Nyungwe National Park Buffer Zone and Implications for Adjacent Communities. Society \& Natural Resources, 28, 296-311. https://doi.org/10.1080/08941920.2014.948246

Hancock, T. (1985). The Mandala of Health: A Model of the Human Ecosystem. Family \& Community Health: The Journal of Health Promotion \& Maintenance, 8, 1-10. https://doi.org/10.1097/00003727-198511000-00002

He, M., \& Cliquet, A. (2020). Challenges for Protected Areas Management in China. Sustainability, 12, 5879. https://doi.org/10.3390/su12155879

Holden, A. (2016). Environment and Tourism. London: Routledge. https://doi.org/10.4324/9781315767659

Holmes, C. M. (2003). The Influence of Protected Area Outreach on Conservation Attitudes and Resource Use Patterns: A Case Study from Western Tanzania. Oryx, 37, 305-315. https://doi.org/10.1017/S0030605303000565

Jamal, T. B., \& Getz, D. (1995). Collaboration Theory and Community Tourism Planning. Annals of Tourism Research, 22, 186-204. https://doi.org/10.1016/0160-7383(94)00067-3

Kaplin, B. A., \& Moermond, T. C. (1998). Variation in Seed Handling by Two Species of Forest Monkeys in Rwanda. American Journal of Primatology, 45, 83-101. https://doi.org/10.1002/(SICI)1098-2345(1998)45:1<83::AID-AJP7>3.0.CO;2-S

Koellner, T., De Baan, L., Beck, T., Brandão, M., Civit, B., Margni, M., Müller-Wenk, R. et al. (2013). UNEP-SETAC Guideline on Global Land Use Impact Assessment on Biodiversity and Ecosystem Services in LCA. The International Journal of Life Cycle Assessment, 18, 1188-1202. https://doi.org/10.1007/s11367-013-0579-Z

Lopoukhine, N., Craw hall, N., Dudley, N., Figgis, P., Karibuhoye, C., Laffoley, D., Sandwith, T. et al. (2012). Protected Areas: Providing Natural Solutions to 21st Century Challenges. SAPI EN. S. Surveys and Perspectives Integrating Environment and Society (5.2).

Malhi, Y., Silman, M., Salinas, N., Bush, M., Meir, P., \& Saatchi, S. (2010). Introduction: Elevation Gradients in the Tropics: Laboratories for Ecosystem Ecology and Global Change Research. Global Change Biology, 16, 3171-3175. https://doi.org/10.1111/j.1365-2486.2010.02323.x

Mihalic, T. (2016). Sustainable-Responsible Tourism Discourse-Towards "Responsustable" Tourism. Journal of Cleaner Production, 111, 461-470. https://doi.org/10.1016/j.jclepro.2014.12.062

Moore, J. F., Mulindahabi, F., Masozera, M. K., Nichols, J. D., Hines, J. E., Turikunkiko, E., \& Oli, M. K. (2018). Are Ranger Patrols Effective in Reducing Poaching-Related Threats within Protected Areas? Journal of Applied Ecology, 55, 99-107. https://doi.org/10.1111/1365-2664.12965

Nibeza, S. (2015). Sustainable Environment, a Key of Sustainable Development a Case Study of Rwanda. International Journal of Research in Economics and Social Sciences, 
5, 20-36.

Ormsby, A., \& Kaplin, B. A. (2005). A Framework for Understanding Community Resident Perceptions of Masoala National Park, Madagascar. Environmental Conservation, 32, 156-164. https://doi.org/10.1017/S0376892905002146

Park, S., Zielinski, S., \& Jeong, Y. (2020). Factors Affecting Residents' Support for Protected Area Designation. Sustainability, 12, 2800. https://doi.org/10.3390/su12072800

Pimbert, M. P., \& Pretty, J. N. (1997). Parks, People and Professionals: Putting "Participation" into Protected Area Management. Social Change and Conservation, 16, 297-330.

Plumptre, A., Masozera, M., Fashing, P., McNeilage, A., Ewango, C., Kaplin, B., \& Liengola, I. (2002). Biodiversity Surveys of the Nyungwe Forest of Southwest Rwanda. Working Paper 19, Bronx, NY: Wildlife Conservation Society.

Polisi, A., Ntahorwaymiye, A. C., Agostini, P., Migraine, J. B., Kobayashi, M., Vaislic, M. D. H., Jumaine, H. et al. (2017). Burundi-Country Environmental Analysis: Understanding the Environment within the Dynamics of a Complex World: Linkages to Fragility, Conflict, and Climate Change. Washington DC: The World Bank.

Rastegar, H. R. (2017). Environmental Protection and Local Resident Attitudes at Early Stages of Tourism Development.

Salafsky, N., \& Wollenberg, E. (2000). Linking Livelihoods and Conservation: A Conceptual Framework and Scale for Assessing the Integration of Human Needs and Biodiversity. World Development, 28, 1421-1438.

https://doi.org/10.1016/S0305-750X(00)00031-0

Saner, R., Yiu, L., \& Filadoro, M. (2019). Tourism Development in Least Developed Countries: Challenges and Opportunities. In Sustainable Tourism: Breakthroughs in Research and Practice (pp. 94-120). Hershey, PA: IGI Global. https://doi.org/10.4018/978-1-5225-7504-7.ch006

Sharpley, R., \& Pearce, T. (2007). Tourism, Marketing and Sustainable Development in the English National Parks: The Role of National Park Authorities. Journal of Sustainable Tourism, 15, 557-573. https://doi.org/10.2167/jost613.0

Struhsaker, P. J., \& Siex, K. S. (2005). Conserving Africa's Rain Forests: Problems in Protected Areas and Possible Solutions. Biological Conservation, 123, 45-54. https://doi.org/10.1016/j.biocon.2004.10.007

Wilcox, L. S. (2008). Fresh Perspectives. The Relationships among Life Stages, Health Behavior, and Chronic Disease. Preventing Chronic Disease, 5, A106-A106.

Worboys, G. L., Lockwood, M., Kothari, A., Feary, S., \& Pulsford, I. (2015). Protected Area Governance and Management. Canberra: ANU Press. https://doi.org/10.22459/PAGM.04.2015

Zamil, A. (2011). The Role of Jordanian Local Community in Marketing Tourism. Journal of Business Studies Quarterly, 2, 42. 